\title{
REGULARITY-CHAOS TRANSITION TEMPERATURE AND GUISBIERS-BUCHAILLOT EQUATION
}

\author{
D. Malivuk ${ }^{*}$, S. Nježić, S. Lekić, Z. Rajilić \\ University of Banja Luka, Faculty of Science and Mathematics, \\ Mladena Stojanovića 2, 78000 Banja Luka, Bosnia and Herzegovina
}

\begin{abstract}
A focus of frontline interdisciplinary research today is the development of the conceptual framework and the experimental background of the science of nanostructured materials and the perspectives of its technological applications. G. Guisbiers and L. Buchaillot found out the general equation (GBE) which was based only on the surface area to volume ratio of nanostructures and statistics (Fermi-Dirac or Bose-Einstein) followed by the particles involved in the considered phenomena (melting, ferromagnetism, vibration and superconductivity). In this paper, we consider another phenomenon, the regularity-chaos transition, and find its connection with GBE. We have performed the computational experiments with one hydrogen molecule and one graphene sheet. $\mathrm{H}_{2}-\mathrm{C}$ interactions are described by Lennard-Jones potential. The main goal of our experiments is find out the critical temperatures of regularity-chaos transition. The results of computation derived using Runge-Kutta-Fehlberg method show approximate agreement with GBE.
\end{abstract}

Keywords: Hydrogen molecule, critical temperature, regularity-chaos transition, Guisbiers-Buchaillot equation.

\section{INTRODUCTION}

Study of size and shape effects on material properties has lately attracted an enormous attention. Understanding how materials behave at tiny length scales is crucial for developing the future nanotechnologies [1]. The advances in nanomaterial modeling together with new characterization tools are the key to study new properties and capabilities, hence to design the devices with improved performance. Nanomaterials have different properties relative to the bulk materials, which is a very important fact. Even so, the determination of nanomaterial properties is still in its infancy and many materials properties are still unknown. Also, theoretical predictions of some characteristic of materials play a very important role. That is very useful when experiment can not be easily done. If we want to discuss modeling nanomaterials, we first have to consider two main approaches. In the "top-down" approach, one looks at the variation of the systems properties that change when going from the macro to the nano dimensions. On the contrary, in the "bottom-up" approach, one starts from atoms and adds more and more atoms, in order to see how the properties are modified. The first one uses the classical thermodynamics, whereas the second relies on computational methods, like molecular dynamics. Molecular dynamics generally considers less than one million atoms in order to keep calculation time within the reasonable values. This factor limits the nanostructure size modeled below the values around $100 \mathrm{~nm}$. By using classical thermodynamics, the "top-down" approach ceases to be valid when thermal energy $k T$ becomes smaller than the energetic gap between two successive levels [2].

A great deal of scientific community today is involved in the research in hydrogen storage on the nanostructure level. It is considered to be one of the most important factors in improving the performance and efficiency of the fuel cells. Because of that, it is very important to know as much as possible about its properties and its interaction with other elements and materials. It is shown that graphene is a very good choice for hydrogen storage $[3,4,5]$.

In this paper, we consider a universal equation of nanoscale, proposed by Guisbiers and Buchaillot $[6,7]$ :

$T_{x} / T_{x, \infty}=\left[1-\alpha_{\text {shape }} / D\right]^{1 / 2 s}$

It only requires the knowledge of the surface area to volume ratio of the nanomaterial, its size, as well as the statistics (Fermi-Dirac or Bose-Einstein) followed by the particles involved in the considered material property. Guisbiers and Buchaillot studied the relation between the material size and shape and characteristic temperatures like melting, Debye, $\mathrm{Cu}-$ rie or superconducting temperatures and proposed a 
unique equation for nanoscale. Here, $D$ is the diameter of the nanostructure, and $\alpha_{\text {shape }}$ is the parameter quantifying the size effect on the characteristic temperature and depends on the nanostructure's shape. The shape parameter is directly proportional to the surface area over volume ratio $A / V$ as indicated by

$\alpha_{\text {shape }}=\left[D\left(\gamma s-\gamma_{l}\right) / \Delta H_{m, \infty}\right](A / V)$

where $\Delta H_{m, \infty}$ is the bulk melting enthalpy and $\gamma_{s(l)}$ the surface energy in the solid (liquid) phase.

In this paper, we will consider another characteristic temperature, the so-called regularitychaos transition temperature $T_{R C}$ (Fig. 1.).

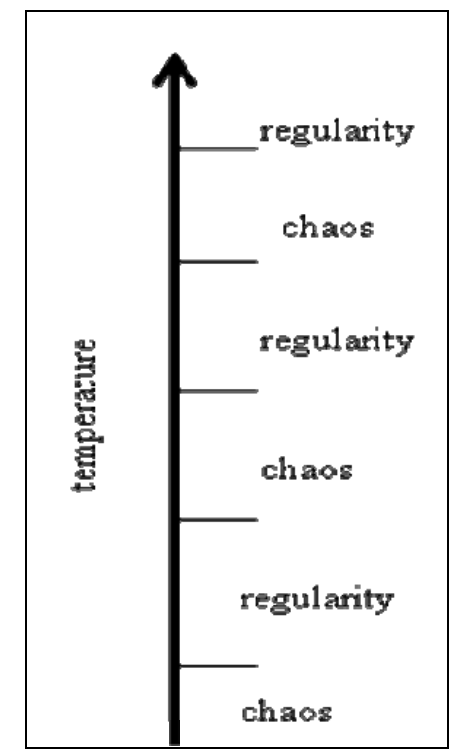

Figure 1. Scheme of the regularity-chaos and chaosregularity transitions for a hydrogen molecule moving near graphene

The results of computation derived using Runge-Kutta-Fehlberg method show approximate agreement with GBE.

\section{METHOD}

Here we consider a hydrogen molecule moving near the graphene sheet with $4 N \times 2 N$ atoms resting in their equilibrium positions. We propose the initial molecule position and velocity $(a=0,142$ $\mathrm{nm}$ is the distance between neighboring $C$ atoms):

$$
\begin{aligned}
& x(0)=3 a \\
& \mathrm{y}(0)=-1 \mathrm{~nm} \\
& z(0)=\frac{(3 N-2) a}{4}+0,05 a \\
& V_{x}(0)=0
\end{aligned}
$$

$$
\begin{aligned}
& V_{y}(0)=\sqrt{\frac{8 k T}{\pi m}} \\
& V_{z}(0)=0
\end{aligned}
$$

In our experiments, $N=6,7 \ldots .12$. If the size of our graphene sheet is evaluated, one can find that its size is within nanoscale.

Hydrogen molecule is interacting with a graphene sheet curved around $z$ axes and we solve the classical equation of motion assuming that the number of carbon atoms and temperature, determining the molecule initial velocity, are large enough. In the chaotic regime, a small change in the initial conditions leads to a large change in $\mathrm{H}_{2}$ molecule behavior. Regular and chaotical motion of the molecule is viewed in the temperature interval between $10 \mathrm{~K}$ and $200 \mathrm{~K}$, with step size of $5 \mathrm{~K}$. One can find several regular-chaos transitions and chaos-regularity transition temperatures. It should be mentioned that we have a step size of $5 \mathrm{~K}$ and that it is probably possible to find some new $T_{R C}$ if the step size is smaller.

Sensitivity to the initial conditions was examined by changing

$z(0) \rightarrow 1,0001 * z(0)$

We have tried to describe the dependence of the regularity-chaos transition temperature on $\mathrm{N}$ by the function

$f(N)=P \sqrt{1-\frac{b}{N}}$

yielded from the relation (1). We will see that, in many cases, for appropriate values of parameters $P$ and $b, f(N)$ approximates to the regularity-chaos transition temperatures.

At large enough $N$ and $T$,we can use the classical mechanics due to the following

$\beta L_{z}=\frac{0.4}{\sqrt{K}}(4 N-1) \sqrt{T} \hbar$

where $\beta$ is curvature of the structure and $L_{z}$ iz $z$ component of the molecule angular momentum. Radius of the graphene sheet curvature is equal to

$\sqrt{3}(4 N-1) a /(2 \beta)$

In the following examples we take $N=12$ and $\beta=0,15 \pi$. In first case (Fig.2.) we see that curves representing trajectories (change velocity in time) are the same, but in the second and third case respectively, (Fig. 3. and Fig. 4) we can see sensitivity to the initial conditions. 


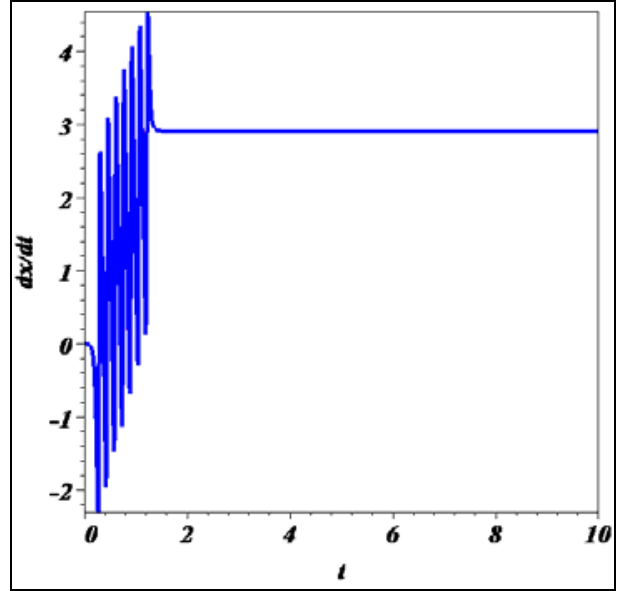

Figure 2. $V_{x}(t)$ at $T=200 \mathrm{~K}$ (curves are the same for very close initial conditions-regularity).

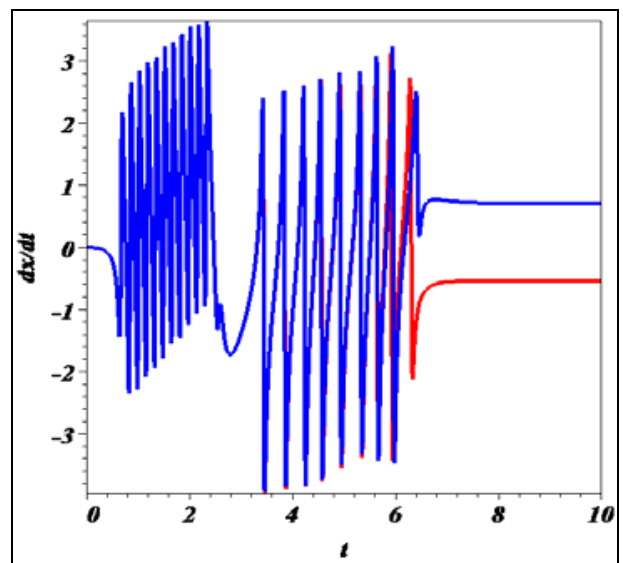

Figure 3. $V_{x}(t)$ at $T=140 \mathrm{~K}$ (curves are different for very close initial conditions-chaos).

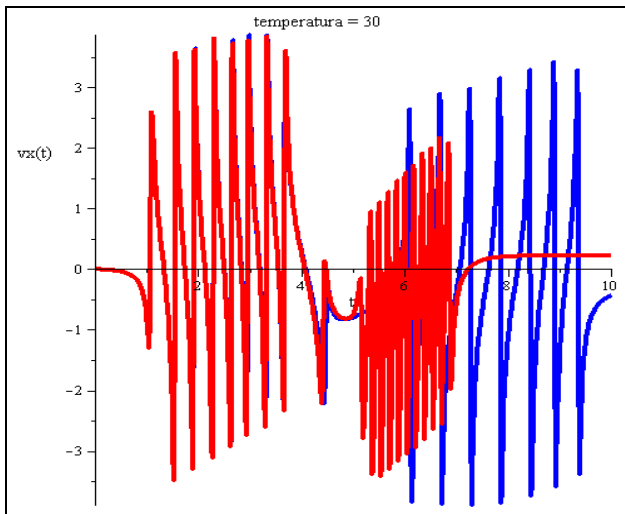

Figure 4. $V_{x}(t)$ at $T=30 \mathrm{~K}$ (large difference in curves for very close initial conditions-chaos)

\section{DEPENDENCE OF TRANSITION TEMPERATURE ON THE STRUCTURE SIZE}

We have performed several computational experiments with different size and shape of graphene sheet in attempt to find out regularity-chaos transi- tion temperature and see if there was any compatibility with GBE. Our results are presented in the following figures. It should be mentioned that there are cases in which we have larger number of transitions, and we can not apply this approach, for example if $\beta= \pm 0,35 \pi$. It is possible to find the other regularitychaos transition temperatures if we use a smaller step size and, in most of cases, there is a problem with implementation of this approach. Also, in some of the cases, there are transitions on higher temperatures which we do not consider in our experiments $(T=10 \mathrm{~K}-200 \mathrm{~K})$, but there are points which belong to some new curve.

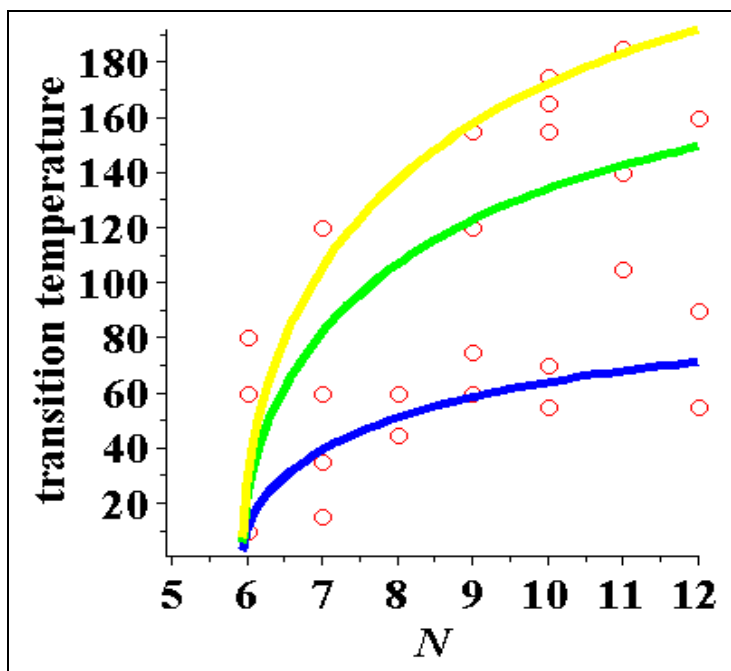

Figure 5. Regularity-chaos transition temperature (kelvin), for $\beta=-0.8 \pi$, found by the computation experiments (red circles) and $f(N)$. Here $b=5,95$ and $P$ is equal to 100 (blue line), 210 (green line), 270 (yellow line).

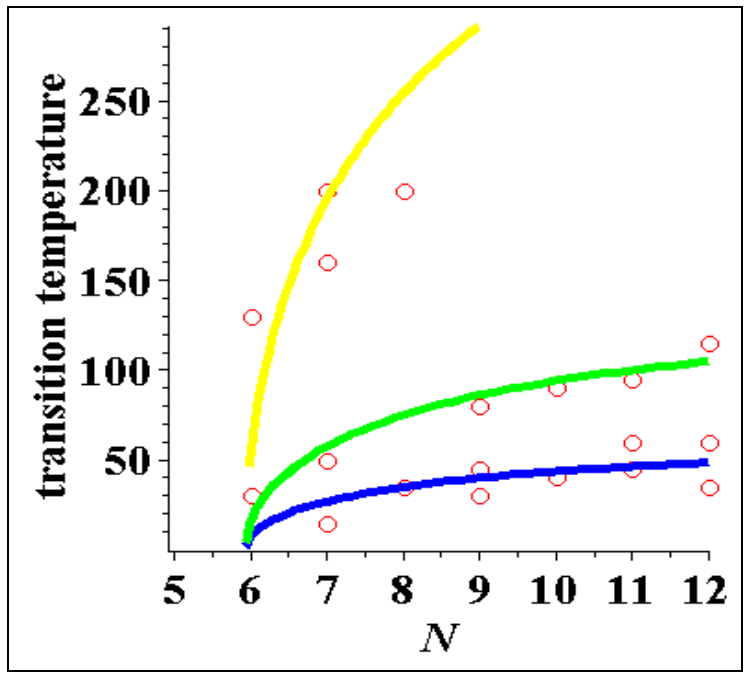

Figure 6. Regularity-chaos transition temperature (kelvin), for $\beta=-0.18 \pi$, found by the computation experiments (red circles) and $f(N)$. Here $b=5,95$ and $P$ is equal to 68 (blue line), 147 (green line), 500 (yellow line). 


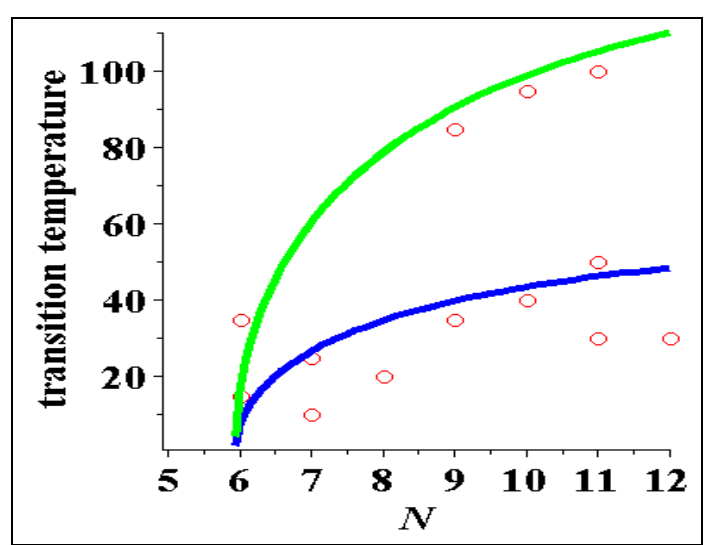

Figure 7. Regularity-chaos transition temperatures (kelvin), for $\beta=0,15 \pi$, found by the computation experiments (red circles) and $f(N)$. Here $b=5,95$ and $P$ is equal to 68 (blue line), 155 (green line)

\section{CONCLUSION}

A great deal of scientific community today is involved in the research in the field of nanotechnology. Because of that, it is very important to know some new properties and characteristics of that material, which are obtained both theoretically and experimentally. Our aim was to find out if the GBE was applicable to new temperature transition, yet uninvestigated in the context of GBE, so-called regularity-chaos transition. It is shown the approximate agreement of this temperature dependence on structure size with GBE.

We should mention that our computational experiments have some shortcomings, the main ones being: (1) a relatively small number of $C$ atoms are considered, (2) $C$ atoms are always placed in their equilibrium positions, (3) we have not considered many possible different velocities at the same temperature, but only the average value.

\section{REFERENCES}

[1] J. Jortner, C. N. R. Rao, Nanostructured advanced materials. Perspectives and directions, Pure Appl. Chem. Vol. 74 (2002)1491-1506.

[2] W. H. Qi, B.Y.Huang, M.P.Wang, Z.Li, Z.M.Yu, Generalized bond-energy model for cohesive energy of small metallic particles, Phys. Lett. A Vol. 370 (2007) 494-498.

[3] T. Enoki, Physics and Chemistry of Graphene, (2009) (Hackensack: Pan Stanford Publishing).

[4] G. K. Dimitrakakis, E. Tylianakis, G. E. Froudakis, Pillared Graphene: A New 3-D Network Nanostructure for Enhanced Hydrogen Storage, Nano Lett. Vol. 8 (2008) 3166-3170.

[5] T. Heine, L. Zhechkov, S. Patchkovskii, G. Seifert, Novel Carbon Materials can Store and Sieve Hydrogen, SPIE Newsroom (2007) 10.1117/ 2.1200704.0714.

[6] G. Guisbiers, Size-Dependent Materials Properties Toward a Universal Equation, Nanoscale Res. Lett. Vol. 5 (2010) 1132-1136.

[7] G. Guisbiers, L. Buchaillot, Universal Size/Shape-Dependent Law for Characteristic Temperatures, Phys. Lett. A Vol. 374 (2009) 305-308.

\section{ТЕМПЕРАТУРА ПРЕЛАЗА РЕГУЛАРНОСТ-ХАОС И ГИЗБИР-БИШЕЛО ЈЕДНАЧИНА}

Сажетак: Изучавање особина наноструктура веома је важно како за науку тако и за примјену наноматеријала у индустрији. Гизбир и Бишело пронашли су универзалну једначину наноструктуре (ГБЈ) која повезује величину и облик наноструктуре као и природу честица које учествују у интеракцији са карактеристичним температурама, као што су температура топљења, Дебајева, Киријева и температура прелаза у суперпроводно стање. У низу рачунарских експеримената ми смо истраживали зависност температуре прелаза регуларност-хаос о облику и величини графенског листа. У експерименту се посматра један молекул водоника и један графенски лист. Интеракција $\mathrm{H}_{2}-\mathrm{C}$ описана је Ленард-Џонсовим потенцијалом. Изучавање особина графена је веома важно за складиштење водоника. Резултати, добијени помоћу Рунге-Кута-Фелбергове методе, приближно се слажу са ГБЈ.

Кључне ријечи: молекул водоника, критична температура, прелаз регуларностхаос, Гизбир-Бишелоова једначина. 